\title{
Multiple regression analysis of anthropometric measurements influencing the cephalic index of male Japanese university students
}

\author{
Md Golam $\underline{\text { Hossain }}^{1}$, MSc, DSc, Aik Saw ${ }^{2}$, MBBS, FRCSE, Rashidul Alam ${ }^{1}$, BSc, MSc, Fumio Ohtsuki ${ }^{3}$, MSc, PhD,
} Tunku $\underline{\text { Kamarul}}^{2}$, MBBS, PhD

INTRODUCTION Cephalic index $(\mathrm{Cl})$, the ratio of head breadth to head length, is widely used to categorise human populations. The aim of this study was to access the impact of anthropometric measurements on the $\mathrm{Cl}$ of male Japanese university students.

METHODS This study included 1,215 male university students from Tokyo and Kyoto, selected using convenient sampling. Multiple regression analysis was used to determine the effect of anthropometric measurements on $\mathrm{Cl}$.

RESULTS The variance inflation factor (VIF) showed no evidence of a multicollinearity problem among independent variables. The coefficients of the regression line demonstrated a significant positive relationship between $\mathrm{Cl}$ and minimum frontal breadth $(p<0.01)$, bizygomatic breadth $(p<0.01)$ and head height $(p<0.05)$, and a negative relationship between $\mathrm{Cl}$ and morphological facial height $(p<0.01)$ and head circumference $(p<0.01)$. Moreover, the coefficient and odds ratio of logistic regression analysis showed a greater likelihood for minimum frontal breadth $(p<0.01)$ and bizygomatic breadth $(p<0.01)$ to predict round-headedness, and morphological facial height $(p<0.05)$ and head circumference $(p<0.01)$ to predict long-headedness. Stepwise regression analysis revealed bizygomatic breadth, head circumference, minimum frontal breadth, head height and morphological facial height to be the best predictor craniofacial measurements with respect to $\mathrm{Cl}$.

CONCLUSION The results suggest that most of the variables considered in this study appear to influence the $\mathrm{Cl}$ of adult male Japanese students.

Keywords: anthropometric measurements, cephalic index, logistic regression, multiple regression, university students

\section{INTRODUCTION}

Head form has been of major interest to human biologists and anthropologists since Anders Retzius (1796-1860), a Swedish professor of anatomy, developed the cephalic index $(\mathrm{Cl})$ as a method of describing head shape in 1842. ${ }^{(1)}$ The $\mathrm{Cl}$, which is derived by dividing maximum head breadth (eu-eu) by maximum head length (g-op) and multiplying the result by 100 , gives the ratio of head breadth to head length. It is widely used not only to categorise human populations, but also to describe an individual's appearance and estimate the age of fetuses for legal and obstetrical purposes. ${ }^{(2)} \mathrm{Cl}$ is also used in the investigation of normal brain development in children. ${ }^{(3)}$ A previous study by Asha et al reported that three variables $-\mathrm{Cl}$, index of head size and morphological upper facial index - could accurately classify patients with Down syndrome. ${ }^{(4)}$ Head form presumably reflects an aspect of brain size, i.e. the longest head length defining the greatest anterior-posterior diameter of the brain case and the widest head breadth representing the greatest transverse diameter of the brain case. If the brain case is short but relatively broader, the head is considered brachycephalic (round-headed), and if the brain case is long but relatively narrower, the head is deemed to be dolichocephalic (long-headed). An increase in $\mathrm{Cl}$ indicates a tendency toward round-headedness.

In the last century, many researchers have used $\mathrm{Cl}$ to describe the characteristics of head forms in different races all over the world. ${ }^{(5-14)}$ In Japan, Suzuki reported the protohistoric Japanese population as long-headed and broad-faced with strong prognathism. ${ }^{(15)}$ Subsequent researchers have also published studies on the $\mathrm{Cl}$ of the Japanese. ${ }^{(16-23)}$ More recently, researchers, such as Hossain et $\mathrm{al}^{(23,24)}$ and Kouchi, ${ }^{(25)}$ have studied secular changes in $\mathrm{Cl}$ over time, attributing the increase in $\mathrm{Cl}$ in the Japanese to an increase in head breadth. ${ }^{(23-25)}$ More recently, Hossain et al have reported that the best predictor dimensions for face form among adult female Japanese students were head length (g-op), head circumference (g-g), head breadth (eu-eu), minimum frontal breadth ( $\mathrm{ft}-\mathrm{ft}$ ) and head height (v-po). ${ }^{(26)}$ This suggests that factors that contribute to changes in the anthropometric measurements of a population can be expected to influence the size and shape of the head of individuals in that population. However, information on the association between changes in general physical form and head form is still lacking. The aim of the present study was to investigate the relationship between anthropometric characteristics and the $\mathrm{Cl}$ of adult male Japanese students.

${ }^{1}$ Department of Statistics, University of Rajshahi, Rajshahi, Bangladesh, ${ }^{2}$ Department of Orthopaedic Surgery, National Orthopaedic Centre of Excellence for Research and Learning, Faculty of Medicine, University of Malaya, Kuala Lumpur, Malaysia, ${ }^{3}$ Laboratory of Human Biology, Tokyo Metropolitan University, Tokyo, Japan Correspondence: Dr Saw Aik, Professor, Department of Orthopaedic Surgery, National Orthopaedic Centre of Excellence for Research and Learning, Faculty of Medicine, University of Malaya, Lembah Pantai 50603, Kuala Lumpur, Malaysia. sawaik@hotmail.com 
Table I. Anthropometric landmarks used for taking craniofacial measurements.

\begin{tabular}{lll}
\hline Measurement & \multicolumn{1}{c}{ Landmarks } \\
\cline { 2 - 3 } & Beginning & End \\
\hline Head length (g-op) & Glabella (g) & Opisthocranion (op) \\
Head breadth (eu-eu) & Left euryon (eu) & Right euryon (eu) \\
Head height ( $\mathrm{v}-\mathrm{po})$ & Vertex $(\mathrm{v})$ & Porion (po) \\
Head circumference $(\mathrm{g}-\mathrm{g})$ & Glabella (g) & Glabella (g) \\
Minimum frontal breadth (ft-ft) & Left frontotemporale (ft) & Right frontotemporale (ft) \\
Bizygomatic breadth (zy-zy) & Left zygion (zy) & Right zygion (zy) \\
Bigonial breadth (go-go) & Left gonion (go) & Right gonion (go) \\
Morphological facial height ( $\mathrm{n}$-gn) & Nasion $(\mathrm{n})$ & Gnathion (gn) \\
\hline
\end{tabular}

\section{METHODS}

Cross-sectional data was collected from 1,215 healthy male Japanese students from several universities in Tokyo and Kyoto from 1998 to 2001. All the subjects were of Japanese birth and ancestry, with representation from various districts of Japan. The age of the subjects at the time of measurement was 18-25 years (average 19.29 \pm 0.98 years). Nine craniofacial measurements were taken: head length (g-op), head breadth (eu-eu), head height (v-po), head circumference (g-g), minimum frontal breadth (ft-ft), bizygomatic breadth (zy-zy), bigonial breadth (go-go), and morphological facial height (n-gn) (Table I). Stature and body weight were also measured. All the measurements were taken by one observer, using the technique described by Martin and Saller. ${ }^{(27)}$ The $\mathrm{Cl}$ was calculated from head breadth (eu-eu) and head length (g-op) as:

$$
\mathrm{Cl}=\frac{\text { Head breadth }(\text { eu-eu) }}{\text { Head length }(\mathrm{g} \text {-op) }} \times 100
$$

The sample used in the present study was divided into six groups according to head size: (i) hyperdolichocephalic (Cl $\leq 71.99)$; (ii) dolichocephalic $(72.00 \leq \mathrm{Cl} \leq 76.99)$; (iii) mesocephalic (77.00 $\leq \mathrm{Cl} \leq 81.99)$; (iv) brachycephalic (82.00 $\leq$ $\mathrm{Cl} \leq$ 86.49); (v) hyperbrachycephalic $(86.50 \leq \mathrm{Cl} \leq 91.99)$; and (vi) ultrabrachycephalic $(\mathrm{Cl} \geq 92.00)$ (Table II). The sample was also divided into two larger groups - round-headedness $(\mathrm{Cl} \geq 82.00)$ and long-headedness $(\mathrm{Cl} \leq 81.99)$.

To examine the average relationship between $\mathrm{Cl}$ and craniofacial measurements, multiple regression analysis was utilised. The underlying multiple linear regression model corresponding to each variable was as follows:

$$
Y=\beta_{0}+\beta_{1} X_{1}+\beta_{2} X_{2}+\beta_{3} X_{3}+\ldots+\beta_{k} X_{k}+\varepsilon
$$

where $\mathrm{Y}$ is the response variable $(\mathrm{Cl}) ; \mathrm{X}_{\mathrm{i}}(\mathrm{i}=1,2,3, \ldots, \mathrm{k})$ values are the predictor variables (anthropometric measurements); $\beta_{0}$ is the intercept term; $\beta_{1}, \beta_{2}, \ldots, \beta_{\mathrm{k}}$ are unknown regression coefficients; and $\varepsilon$ is the error term with a $N\left(0, \sigma^{2}\right)$ distribution.

In multiple regression analysis, an important assumption is that the explanatory variables are independent of each other, i.e. there is no relationship between the explanatory variables used to estimate ordinary least squares. However, in some applications of regression, the explanatory variables are, in fact, related to each other. This is called the multicollinearity problem. ${ }^{(28)}$ In this study, the variance inflation factor (VIF) was used to check for the problem of multicollinearity among the predictor variables. The variance inflation for independent variables $\mathrm{X}_{\mathrm{j}}$ is:

$$
\mathrm{VIF}_{\mathrm{j}}=\frac{1}{\left(1-\mathrm{R}_{\mathrm{j}}{ }_{\mathrm{j}}\right)}, \mathrm{j}=1,2, \ldots, \mathrm{p}
$$

where $p$ is the number of predictor variables and $R^{2}$ is the square of the multiple correlation coefficient. If (i) $0<\mathrm{VIF}<5$, there is no evidence of multicollinearity problem; (ii) $5 \leq$ VIF $\leq 10$, there is moderate multicollinearity problem; and (iii) VIF $>10$, there is serious multicollinearity problem with the variables.

Logistic regression was used to determine the effect of anthropometric measurements on the roundness of head. Finally, stepwise regression analysis was used to select the best predictor variables for $\mathrm{Cl}$. Statistical analyses were carried out using the Statistical Package for the Social Sciences version 15 (SPSS Inc, Chicago, IL, USA).

\section{RESULTS}

For the parametric test, the $\mathrm{Cl}$ was checked for normality using the Kolmorov-Smirnov test and found to be normally distributed. Thus, the data used in the current study satisfied the standard assumptions of parametric tests. Since the $\mathrm{Cl}$ was calculated from head breadth and head length, these two measurements were excluded from analysis.

Linear regression coefficients demonstrated that increasing mean values of minimum frontal breadth ( $\mathrm{ft}-\mathrm{ft})(\mathrm{p}<0.01)$ and bizygomatic breadth $(g-g)(p<0.01)$ tended to coincide with the change of head form toward roundedness, whereas head circumference $(g-g)$ showed a negative tendency $(p<0.05)$ (Table II). The linear multiple regression model used was:

$$
\begin{aligned}
\mathrm{Cl}= & \beta_{0}+\beta_{1}(\mathrm{ft}-\mathrm{ft})+\beta_{2}(\mathrm{zy}-\mathrm{zy})+\beta_{3}(\mathrm{go}-\mathrm{go})+\beta_{4}(\mathrm{v}-\mathrm{po})+ \\
& \beta_{5}(\mathrm{n}-\mathrm{gn})+\beta_{6}(\mathrm{~g}-\mathrm{g})+\beta_{7} \mathrm{St}+\beta_{8} W \mathrm{t}+\varepsilon
\end{aligned}
$$

where $\mathrm{Cl}$ is a response variable and other variables were predictors; $\mathrm{St}=$ stature $(\mathrm{cm})$ and $\mathrm{Wt}=$ body weight $(\mathrm{kg})$. 
Table II. Anthropometric measurements according to the shape of the head.

\begin{tabular}{lcccccc}
\hline $\begin{array}{l}\text { Anthropometric } \\
\text { measurement }\end{array}$ & $\begin{array}{c}\text { Dolichocephalic } \\
(\mathbf{n}=\mathbf{3 0})\end{array}$ & $\begin{array}{c}\text { Mesocephalic } \\
(\mathbf{n}=\mathbf{2 2 2})\end{array}$ & $\begin{array}{c}\text { Brachycephalic } \\
(\mathbf{n}=\mathbf{5 0 7})\end{array}$ & $\begin{array}{c}\text { Hyper- } \\
\text { brachycephalic } \\
(\mathbf{n}=\mathbf{3 7 8})\end{array}$ & $\begin{array}{c}\text { Ultra- } \\
\text { brachycephalic } \\
(\mathbf{n}=\mathbf{7 8})\end{array}$ & $\begin{array}{c}\text { Regression } \\
\text { coefficient }\end{array}$ \\
\hline MFB (ft-ft) (mm) & $123.07 \pm 5.04$ & $125.50 \pm 6.39$ & $127.36 \pm 6.00$ & $129.66 \pm 6.41$ & $130.81 \pm 6.32$ & $1.96^{*} ; R^{2}=0.99$ \\
BIZB (zy-zy) (mm) & $141.67 \pm 5.00$ & $143.41 \pm 5.22$ & $145.26 \pm 4.70$ & $146.92 \pm 4.95$ & $148.46 \pm 4.97$ & $1.71^{*} ; R^{2}=0.99$ \\
BIGB (go-go) (mm) & $98.17 \pm 8.26$ & $94.93 \pm 8.08$ & $95.51 \pm 7.93$ & $96.66 \pm 8.50$ & $98.61 \pm 8.53$ & $0.26 ; R^{2}=0.07$ \\
HHt (v-po) (mm) & $135.83 \pm 5.97$ & $133.06 \pm 7.35$ & $133.11 \pm 7.33$ & $133.58 \pm 7.14$ & $133.62 \pm 7.71$ & $-0.39 ; R^{2}=0.29$ \\
MFHt (n-gn) (mm) & $120.10 \pm 11.32$ & $123.07 \pm 10.19$ & $122.82 \pm 10.42$ & $121.98 \pm 10.60$ & $120.49 \pm 11.17$ & $-0.03 ; R^{2}=0.01$ \\
HC (g-g) (cm) & $58.15 \pm 1.47$ & $57.50 \pm 1.41$ & $57.26 \pm 1.36$ & $57.11 \pm 1.39$ & $56.99 \pm 1.56$ & $-0.27^{\dagger} ; R^{2}=0.87$ \\
Stature (cm) & $173.52 \pm 5.21$ & $172.64 \pm 5.49$ & $171.27 \pm 5.42$ & $171.48 \pm 5.39$ & $171.54 \pm 6.03$ & $-0.51 ; R^{2}=0.71$ \\
Weight (kg) & $61.44 \pm 6.52$ & $62.25 \pm 7.75$ & $61.10 \pm 7.62$ & $61.66 \pm 7.70$ & $63.19 \pm 8.26$ & $0.29 ; R^{2}=0.32$ \\
\hline
\end{tabular}

Dolichocephalic $72.00 \leq \mathrm{Cl} \leq 76.99$; Mesocephalic $77.00 \leq \mathrm{Cl} \leq 81.99$; Brachycephalic $82.00 \leq \mathrm{Cl} \leq 86.49$; Hyperbrachycephalic $86.50 \leq \mathrm{Cl} \leq 91.99$; Ultrabrachycephalic $\mathrm{Cl} \geq 92.00$; ${ }^{\ddagger}$ Linear trend; ${ }^{*} 1 \%$ level of significance; ${ }^{\dagger} 5 \%$ level of significance

BIGB: bigonial breadth; BIZB: bizygomatic breadth; Cl: cephalic index; HC: head circumference; HHt: head height; MFB: minimum frontal breadth; MFHt: morphological face height; SD: standard deviation

Table III. Multiple regression coefficients and variance inflation factor (VIF) for the measurements, with the cephalic index as the response variable.

\begin{tabular}{lcc}
\hline Predictor & Coefficient & VIF \\
\hline MFB (ft-ft) & $0.14795^{*}$ & 1.6 \\
BIZB (zy-zy) & $0.38878^{*}$ & 1.9 \\
BIGB (go-go) & -0.02695 & 1.6 \\
HHt (v-po) & $0.03471^{\dagger}$ & 1.4 \\
MFHt (n-gn) & $-0.04003^{*}$ & 1.5 \\
HC (g-g) & $-1.29051^{*}$ & 1.7 \\
Stature & -0.03373 & 1.3 \\
Weight & -0.02448 & 1.6 \\
\hline
\end{tabular}

Coefficient $\mathrm{R}^{2}=28.1 \%$; ${ }^{*} 1 \%$ level of significance. ${ }^{\dagger} 5 \%$ level of significance. BIGB: bigonial breadth; BIZB: bizygomatic breadth; HC: head circumference; $\mathrm{HHt}$ : head height; MFB: minimum frontal breadth; MFHt: morphological face height

The estimated model obtained was:

$$
\begin{aligned}
C \hat{\imath}= & 89.0+0.148(f t-f t)+0.389(z y-z y)- \\
& 0.0269(\text { go-go })+0.0347(v-p o)-0.0400(n-g n)- \\
& 1.29(g-g)-0.0337 \mathrm{St}-0.0245 \mathrm{Wt}
\end{aligned}
$$

where $\mathrm{St}=$ stature $(\mathrm{cm})$ and $\mathrm{Wt}=$ body weight $(\mathrm{kg})$.

The VIF showed that there was no evidence of a multicollinearity problem among the predictor variables (Table III). Therefore, the important assumption of multiple linear regression analysis was satisfied in the data set. The coefficient of the regression line demonstrated a significant positive association between $\mathrm{Cl}$ and minimum frontal breadth $(\mathrm{ft}-\mathrm{ft}$ ) $(p<0.01)$, bizygomatic breadth (zy-zy) $(p<0.01)$ and head height $(v-p o)(p<0.05)$, while a negative relationship was found between $\mathrm{Cl}$ and morphological facial height (n-gn) $(\mathrm{p}<0.01)$ and head circumference $(\mathrm{g}-\mathrm{g})(\mathrm{p}<0.01)$ (Table III).

The coefficients and odds ratio of the logistic regression analysis showed that minimum frontal breadth (ft-ft) $(\mathrm{p}<0.01)$ and bizygomatic breadth (zy-zy) $(p<0.01)$ were far more likely to predict round-headedness, while morphological facial height ( $\mathrm{n}$-gn) $(\mathrm{p}<0.05)$, head circumference $(\mathrm{g}-\mathrm{g})(\mathrm{p}<0.01)$ and
Table IV. Logistic regression results of measurements on the cephalic index.

\begin{tabular}{lcccc}
\hline Measurements & Coefficients & SE & Wald & OR \\
\hline MFB (ft-ft) & $0.078^{*}$ & 0.016 & 23.000 & 1.081 \\
BIZB (zy-zy) & $0.210^{*}$ & 0.023 & 84.217 & 1.234 \\
BIGB (go-go) & -0.013 & 0.012 & 1.075 & 0.987 \\
HHt (v-po) & 0.017 & 0.013 & 1.926 & 1.018 \\
MFHt (n-gn) & $-0.015^{\dagger}$ & 0.009 & 2.724 & 0.985 \\
HC (g-g) & $-0.589^{*}$ & 0.068 & 74.270 & 0.555 \\
Stature & -0.027 & 0.014 & 3.514 & 0.973 \\
Weight & $-0.033^{\dagger}$ & 0.012 & 8.081 & 0.968 \\
\hline
\end{tabular}

${ }^{*} 1 \%$ level of significance. ${ }^{\dagger} 5 \%$ level of significance.

BIGB: bigonial breadth; BIZB: bizygomatic breadth; HC: head circumference; $\mathrm{HHt}$ : head height; MFB: minimum frontal breadth; MFHt: morphological face height; OR: odds ratio; SE: standard error

weight $(p<0.05)$ were less likely to do so. The odds ratio and regression coefficients showed that if an individual was round-headed, the probability of minimum frontal breadth (ft-ft) and bizygomatic breadth (zy-zy) would respectively be $8.1 \%$ and $23.4 \%$ higher than that for a long-headed individual, while the probability of morphological facial height (n-gn), head circumference $(\mathrm{g}-\mathrm{g}$ ) and weight would respectively be $99.0 \%, 56.0 \%$ and $97.0 \%$ lower than that for a long-headed individual (Table IV).

The stepwise regression analysis showed that bizygomatic breadth (zy-zy) was included in the first step. An $\mathrm{R}^{2}$ value of $10.44 \%$ indicated that there was a $10.44 \%$ reduction in the total variation of the $\mathrm{Cl}$ due to the predictor variable, bizygomatic breadth (zy-zy). The second step included both the bizygomatic breadth (zy-zy) and head circumference (g-g), and the $\mathrm{R}^{2}$ value of $23.17 \%$ indicated a $23.17 \%$ reduction in the total variation of the $\mathrm{Cl}$ due to these two predictor variables. The third step, which included bizygomatic breadth (zy-zy), head circumference ( $\mathrm{g}-\mathrm{g}$ ) and minimum frontal breadth (ft-ft), yielded an $\mathrm{R}^{2}$ value of $26.27 \%$, indicating a $26.27 \%$ reduction in the total variation of the $\mathrm{Cl}$ due to these three variables. 
Table V. Summary of the stepwise regression analysis for craniofacial measurements, with cephalic index as the response variable.

\begin{tabular}{|c|c|c|c|c|c|c|}
\hline \multirow[t]{2}{*}{ Parameter } & \multicolumn{6}{|c|}{ Coefficient } \\
\hline & Step 1 & Step 2 & Step 3 & Step 4 & Step 5 & Step 6 \\
\hline BIZB (zy-zy) & $0.265^{*}$ & $0.447^{*}$ & $0.357^{*}$ & $0.356^{*}$ & $0.368^{*}$ & $0.372^{*}$ \\
\hline $\mathrm{HC}(\mathrm{g}-\mathrm{g})$ & - & $-1.261^{*}$ & $-1.324^{*}$ & $-1.386^{*}$ & $-1.354^{*}$ & $-1.309^{*}$ \\
\hline MFB (ft-ft) & - & - & $0.139^{*}$ & $0.145^{*}$ & $0.140^{*}$ & $0.139 *$ \\
\hline HHt (v-po) & - & - & - & $0.042^{+}$ & $0.046^{+}$ & $0.046^{+}$ \\
\hline MFHt (n-gn) & - & - & - & - & $-0.030^{+}$ & $-0.028^{+}$ \\
\hline Stature & - & - & - & - & - & $-0.048^{+}$ \\
\hline No. of variable & 1 & 2 & 3 & 4 & 5 & 6 \\
\hline$R^{2}(\%)$ & 10.44 & 23.17 & 26.27 & 26.75 & 27.27 & 27.63 \\
\hline
\end{tabular}

${ }^{\star} 1 \%$ level of significance. ${ }^{\dagger} 5 \%$ level of significance.

BIZB: bizygomatic breadth; HC: head circumference; HHt: head height; MFB: minimum frontal breadth; MFHt: morphological face height

Bizygomatic breadth (zy-zy), head circumference (g-g), minimum frontal breadth ( $\mathrm{ft}-\mathrm{ft}$ ) and head height ( $\mathrm{v}-\mathrm{po})$ were included in the fourth step, with an $\mathrm{R}^{2}$ value of $26.75 \%$, indicating a $26.75 \%$ reduction in the total variation of the $\mathrm{Cl}$ due to these four variables. The fifth step included the previous four variables and morphological facial height (n-gn) with coefficient, which led to a $27.27 \%$ reduction in the total variation of the $\mathrm{Cl}$. The final step, which included the five variables in the fifth step and stature (St), led to a $27.63 \%$ reduction in the total variation of the $\mathrm{Cl}$ due to these six variables (Table V). These results suggest that bizygomatic breadth (zy-zy), head circumference (g-g), minimum frontal breadth (ft-ft), head height (v-po) and morphological facial height (n-gn) were important anthropometric measurements that influenced the $\mathrm{Cl}$.

\section{DISCUSSION}

Multiple regression, logistic regression and stepwise regression analyses were used in the present study to identify craniofacial measurements that influence the head form (i.e. $\mathrm{Cl}$ ) of adult male Japanese students. These statistical analyses demonstrated that most of the craniofacial measurements (except bigonial breadth) were important factors influencing $\mathrm{Cl}$. The coefficients of the regression line showed a positive relationship between $\mathrm{Cl}$ and minimum frontal breadth (ft-ft) and bizygomatic breadth (zy-zy), while a negative relationship was found between $\mathrm{Cl}$ and morphological facial height ( $\mathrm{n}$-gn) and head circumference ( $\mathrm{g}$-g). These results suggest that if an individual has larger minimum frontal breadth (ft-ft), bizygomatic breadth (zy-zy) and head height (v-po), as well as shorter morphological facial height (n-gn) and head circumference (g-g), the individual would also have a more rounded head form.

To the best of our knowledge, there are currently no comparable studies available that document the relationship between $\mathrm{Cl}$ and other craniofacial measurements. Consequently, the present findings cannot be compared to those of other studies. However, there are previous studies ${ }^{(20,23-25)}$ that have reported the positive association of head breadth, and the negative association of head length, with $\mathrm{Cl}$. These results suggest that if head breadth increases and head length decreases, then the shape of the head (i.e. $\mathrm{Cl}$ ) would become more rounded. Although the protohistoric Japanese population has been known to be long-headed and broad-faced with strong prognathism, ${ }^{(16)}$ there is now general agreement that the head form of recent Japanese adults is now brachycephalic. ${ }^{(19-25,29,30)}$ Suzuki's findings concluded that the prevailing brachycephalisation in the Japanese population was due to a decrease in head length and an increase in the head breadth. ${ }^{(17)}$ Ivanovsky ${ }^{(31)}$ and Suzuki ${ }^{(32)}$ have also suggested that the soft tissue structures overlying the cranial bones could have changed over time in response to better nutrition. This may have differentially affected the soft tissue component of head breadth more than head length, although evidence of this remains lacking. In our study, we excluded head length (g-op) and head breadth (eu-eu) from the analyses since the $\mathrm{Cl}$ was derived from these two measurements.

The current study considered only anthropometric measurements to identify measurements that influence the head form of adult male Japanese students. Other external and internal factors, such as genetics, ${ }^{(6)}$ environmental factors, ${ }^{(6,33)}$ dietary protein, ${ }^{(34)}$ psychological and physiological stress, ${ }^{(34)}$ medical facilities and care, ${ }^{(34)}$ and natural climates, ${ }^{(13,33,35)}$ have been proposed to potentially influenced head form. Other hypothesised factors that could potentially influence head form include heterosis, ${ }^{(36)}$ socioeconomic status ${ }^{(37-39)}$ and nutrition or diet. ${ }^{(40)}$ Some researchers believe that the brachycephalic head form has been selected as a consequence of evolutionary forces. ${ }^{(9,41)}$ Presumably, the answer is multifactorial and consists of a combination of various factors. Therefore, more research is required.

\section{REFERENCES}

1. Carol RE, Melvin RE, Peter NP. Physical Anthropology and Archaeology. 2nd ed. New Jersey: Prentice Hall, 2006.

2. Gray DL, Songster GS, Parvin CA, Crane JP. Cephalic index: a gestational age-dependent biometric parameter. Obstet Gynecol 1989; 74:600-3.

3. Koizumi T, Komuro Y, Hashizume K, Yanai A. Cephalic index of Japanese children with normal brain development. J Craniofac Surg 2010; 21:1434-7.

4. Asha KR, Lakshmiprabha S, Nanjaiah CM, Prashanth SN. Craniofacial anthropometric analysis in Down syndrome. Indian J Pediatr 2011; 78:1091-5. 
5. Weidenreich F. The brachycephalization of recent mankind. SW J Anthropol 1945; 1:1-54.

6. Abbie AA. Head form and human evolution. J Anat 1947; 81(pt 3):233-58.

7. Baer MJ. Dimensional changes in the human head and face in the third decade of life. Am J Phys Anthropol 1956; 14:557-75.

8. Roche AF, Seward FS, Sunderland S. Growth changes in the Mongoloid head. Acta Paediatr 1961; 50:133-40.

9. Bielicki T, Welon Z. The operation of natural selection on human head form in an East European population. Homo 1964; 15:22-30.

10. Huizinga J, Slob A. Progressive brachycephalization: reproduction and headform in the Netherlands. A preliminary report. Proc K Ned Akad Wet C 1965; 68:297-301.

11. Jorgensen JB, Drenhaus U, Skrobak-Kaczynski J. [Changes in the physical characteristics of Greenland eskimos from the northern district of Upernarvik]. Anthropo Anz 1974; 34:89-101. German.

12. Skrobak-Kaczynski J, Jorgensen JB, Drenhaus U. Secular changes in the Eskimos of the northern district of Upernavik. J Hum Evol 1977; 6:217-20.

13. Bharati S, Som S, Bharati $P$, Vasulu TS. Climate and head form in India. AmJ Hum Biol 2001; 13:626-34.

14. Golalipour MJ. The effect of ethnic factor on cephalic index in 17-20 years old females of North of Iran. Int J Morphol 2006; 24:319-22.

15. Suzuki $H$. Changes in the skull features of the Japanese people from ancient to modern times. In Men and Cultures. Philadelphia: University of Pennsylvania Press, 1956: 717-24.

16. Suzuki H. [Secular changes of the physical characteristics of the Japanese people from the prehistoric to modern times]. Kaibogaku Zasshi 1967; 42:13-5. Japanese.

17. Suzuki H. Microevolutional changes in the Japanese population from the prehistoric age to present-day. J Fac Sci Univ 1969; 3:279-309.

18. Morita S, Ohtsuki F. Secular changes of the main head dimensions in Japanese. Hum Biol 1973; 45:151-65.

19. Yanagisawa S, Kondo S. Modernization of physical features of the Japanese with special reference to leg length and head form. J Hum Ergol (Tokyo) 1973; 2:97-108.

20. Ohtsuki F, Ito K. Secular changes in head dimensions among Japanese females. Presented at XI International Congress of Anatomy, August 17-23, 1980; Mexico city, Mexico.

21. Kouchi M. Geographic variation in modern Japanese somatometric data: A secular change hypothesis. Univ Mus Univ Tokyo Bull 1986; 27:93-106.

22. Kondo S, Wakatsuki E, Shibagaki H A Somatometric study of the head and face in Japanese adolescents. Okajimas Folia Anat Jpn 1999; 76:179-85

23. Hossain MD, Lestrel PE, Ohtsuki F. Secular changes in head dimensions of Japanese females over eight decades. Anthropol Sci 2004; 112:213-18.

24. Hossain MD, Lestrel PE, Ohtsuki F. Secular changes in head dimensions of Japanese adult male students over eight decades. Homo 2005; 55:239-50.

25. Kouchi M. Brachycephalization in Japan has ceased. Am J Phys Anthropol 2000; 112: 339-47.

26. Hossain MG, Saw A, Ohtsuki F, Lestrel PE, Kamarul T. Change in facial shape in two cohorts of Japanese adult female students twenty years apart. Singapore Med J 2011; 52:818-23.

27. Martin R, Saller K. Lehrbuch der Anthroplogie in systematischer Darstellung. Bd 1. Stuttgart: Fischer, 1957. German.

28. Chatterjee S, Hadi AS. Regression analysis by example. 4th ed. New York: John Wiley \& Sons, 2006

29. Ohtsuki F, Iwamura E. Geographical differences in head and face dimensions among Japanese females. Am J Phys Anthropol 1980; 52:264.

30. Nakashima T. Brachycephalization in the head form of school girls in North Kyushu. J UOEH 1986; 8:411-4.

31. Ivanovsky A. Physical modifications of the population of Russia under famine. Am J Phys Anthropol 1923; 6:331-53.

32. Suzuki H. On the thickness of soft tissues of the head. Anthropol Sci Nippon 1948; 60:7-11.

33. Beals KL, Smith CL, Dodd SM. Climate and the evolution of brachycephalization. Am J Phys Anthropol 1983; 62: 425-37.

34. Miller PS. Secular changes among the Western Apache. Am J Phys Anthropol 1970; 33:197-206.

35. Crognier E. Climate and anthropological variations in Europe and the Mediterranean area. Ann Hum Biol 1981; 8:99-107.

36. Billy G. Anthropometric evidence of exogamy related to secular changes in presentday populations. J Hum Evol 1975; 4:517-20.

37. Schwidetzky I. [Endogamy and anthropological differentiation in the Canary Islands. (Anthropological studies in the Canary Islands 3)]. Z Morphol Anthropol 1973; 65:1-13. German.

38. Pälsson J, Schwidetzky I. [The variability of anthropological characteristics in Iceland after endogamy/exogamy, ages and social groups]. HOMO 1973; 24:23-34. German.

39. Miki Z. Social stratification and the brachycraniazation process in the Medieval period. The Stecci population of Yugoslavia. Homo 1990; 41:136-45.

40. Lasker GW. Migration and physical differentiation. Am J Phys Anthropol 1946; 4:273-300.

41. Henneberg M. The influence of natural selection on brachycephalization in Poland. Stu Phys Anthropol 1976; 2:3-19. 